\title{
A CRYSTALLOGRAPHIC STUDY OF THE PERENNIALLY FROZEN ICE SURFACE OF PATTERNED LAKE, FRAMNES MOUNTAINS, EAST ANTARCTICA
}

\author{
By J.L.C. CHAMBERS, C.J.L. WILSON, \\ (School of Earth Sciences, University of Melbourne, Parkville, Victoria 3052, Australia) \\ and D.A. ADAMSON \\ (School of Biological Sciences and Quaternary Research Unit, Macquarie University, North Ryde, \\ New South Wales 2113, Australia)
}

ABSTRACT. Interlocking rectangular ice patterns, with dimensions of several metres, on the surface of a perennial frozen lake in East Antarctica can be related to a strong crystallographic orientation in the underlying ice. Most of the surface patterns are characterized by parallel centimetrescale ridges and furrows that correspond to an aggregate of tabular-shaped grains. Grain elongation is parallel to the basal plane. The $c$-axis distribution within each ice pattern lies in a horizontal plane. It defines a discrete maximum perpendicular to the surface ridges and to the long axis of the rectangular pattern. Areas exhibiting no patterning are composed of variably orientated ice grains. The strong $c$-axis horizontal orientation and the distinctive morphology of these ice patterns are interpreted as having developed by a geometric enhancement over a long period of time.

RÉsumÉ. Une étude cristallographique de la surface de glace gelée en permanence du Patterned Lake, Framnes Mountains, Antarctique de l'est. Les figures rectangulaires intriquées de glace, multimétriques, à la surface d'un lac gelé en permanence dans l'Est de l'Antarctique peuvent être associées à une forte orientation cristallographique de la glace sous-jacente. La plupart des figures de surfaces sont caractérisées par des rides centimétriques parallèles et des entailles qui correspondent à un agrégat de grains de forme tabulaire. La répartition des axes $c$ dans chaque figure de glace se situe dans un plan horizontal. Cela définit un maximum fini perpendiculaire aux rides de surface et à la

\section{INTRODUCTION}

Distinct morphological features exist on the surface of a perennial ice layer that caps Patterned Lake at the northern end of the Central Masson Range in Mac.Robertson Land, East Antarctica (Fig. 1). The remarkable ice patterning on the surface of this lake was found in 1979 (Pickard and Adamson, 1983) and a detailed study was carried out in February 1985. This paper describes these surface features and relates them to the fabric observed in the ice. Patterns of crystal orientation developed in frozen bodies of water vary considerably within both lake ice (Michel and Ramseier, 1971) and sea ice (Weeks and Ackley, 1982). Observed c-axis variations can be related both to ice morphology and to the processes of ice growth.

Horizontal $c$-axes are a well-documented feature of both sea ice and lake ice, and alignment of horizontal $c$-axes in sea ice has been studied extensively (e.g. Weeks and Ackley, 1982).

Perennially frozen pro-glacial lakes are a feature of the Antarctic continent and are common in the Framnes Mountains (Pickard and Adamson, 1983). Patterned Lake is about $20 \mathrm{ha}$ in area and has a permanent ice cover at least plus grande dimension des figures rectangulaires. Les surfaces dépourvues de figures présentent des orientations variables dans les grains de glace. La forte orientation horizontale des axes $c$ et la morphologie différente de ces figures de glace sont interprétées comme le développement d'un effet géométrique portant sur une longue période de temps.

ZUSAMMENFASSUNG. Eine kristallographische Studie der ständig gefrorenen Oberfläche des Patterned Lake, Framnes Mountains, Ost-Antarktika. Ein ineinandergreifendes Rechteckmuster mit Dimensionen von einigen Metern auf der Oberfläche eines dauernd zugefrorenen Sees in Ost-Antarktika kann zu einer starken kristallographischen Orientierung in dem darunter liegenden Eis in Beziehung gesetzt werden. Die Mehrzahl der Oberflächenmuster ist durch parallele Rücken und Furchen im Zentimeterbereich gekennzeichnet, die einer Anhäufung von tischförmigen Körnern entsprechen. Die Längsrichtung der Körner ist parallel zur Grundfläche. Die Verteilung der $c$-Achsen innerhalb jedes Musters liegt in einer horizontalen Ebene; sie bestimmt ein diskretes Maximum senkrecht zu den Rücken an der Oberfläche und zur grossen Achse der Rechtecksmuster. Gebiete ohne Musterbildung bestehen aus unterschiedlich orientierten Eiskörnern. Die starke horizontale Orientierung der $c$-Achsen und die besondere Morphologie dieser Eismuster werden als Auswirkung einer geometrischen Zwangskraft über einen langen Zeitraum gedeutet.

$4 \mathrm{~m}$ thick. It is typical of perennially frozen lakes found at glacier/rock margins in that it occupies a topographic low and represents decay of stationary glacial ice that has been trapped during a general lowering of the East Antarctic ice sheet. It is further isolated from the effects of glacial movement by the topography of the enclosing mountains. Characteristically, perennially frozen lakes in the Framnes Mountains have a moat isolating central perennial ice which is elevated a few tens of centimetres above the level of the moat (Fig. 2). Water accumulation occurs, particularly in the moat, during summer through the melting of winter snow banks of adjacent rocky bluffs and activation of glacial melt streams which drain into the lake. Since there is no apparent surface or sub-surface drainage leaving Patterned Lake, evaporation is the only known method of water loss. Thus, ice that forms at the bottom of the perennial ice block will eventually be exposed and ablated from the lake surface. This process may take around 20 years to complete if ablation rates measured in the vicinity of the Masson Range (Crohn, 1959; Budd, 1967; Illingsworth, unpublished) of between 18 and $25 \mathrm{~cm}$ of ice per year are typical However, the occurrence of inclusions of melt water, which form during summer below about $0.7-1.0 \mathrm{~mm}$ from the surface, complicate this simple model. In February 985, the 

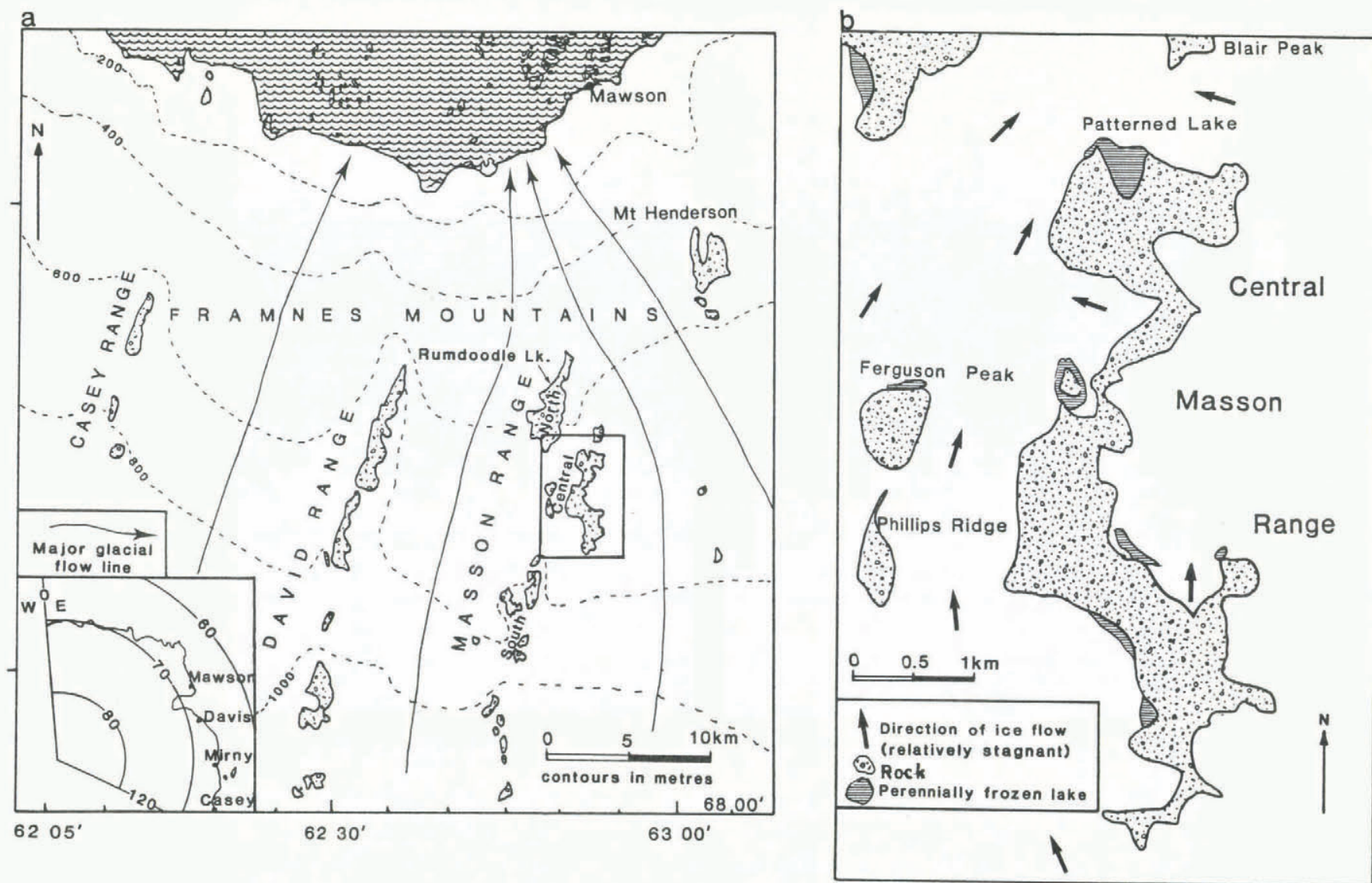

Fig. 1. (a) Map showing the location of the Masson Ranges in the Framnes Mountains in Mac.Robertson Range. Antarctica. (b) Location map showing the position of Patterned Lake in the Central Masson
Rand

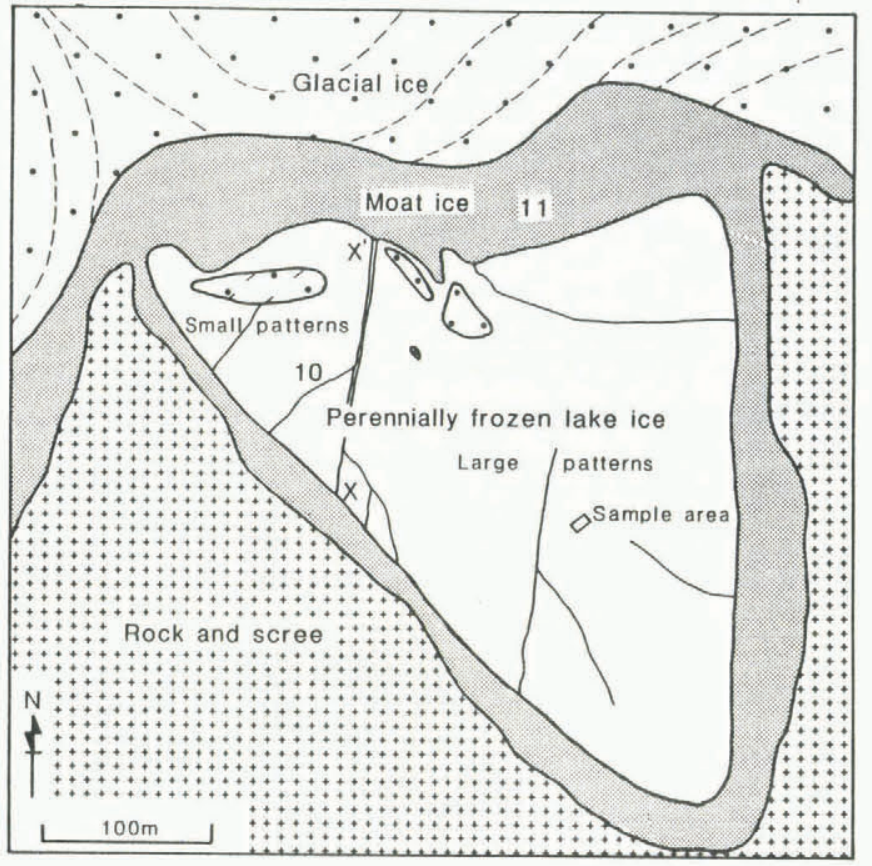

Fig. 2. Ice-type distribution on the surface of Patterned Lake in the Central Masson Range. $\mathrm{xx}$ marks the position of a major cross-cutting fracture. Numbers refer to samples as recorded in Table I. The marked sample area is the location of samples 3-9.

perennial ice contained numerous pockets of melt water which prevented the recovery of ice cores. We infer that the ice block had become porous due to heat absorption, without substantial thinning. Lakes in the Framnes Mountains are fresh water with the depths of some exceeding $100 \mathrm{~m}$ (Pickard and Adamson, 1983). The depth of Patterned Lake has not been determined but it is likely to be at least $50 \mathrm{~m}$ by comparison with other lakes of similar size in the embayments of the mountains.

\section{DESCRIPTION OF ICE TYPES OF PATTERNED LAKE}

Three distinct ice types exist within Patterned Lake: glacier ice, annual moat ice, and perennial lake ice. The distribution of these different ice types is shown in Figure 2 .

Glacier ice is whiter than other types. It shows typical glacier-ice features such as flow lines and cryoconite holes. A study of glacier-ice fabrics in the vicinity of the Framnes Mountains has been made by Kizaki (1969[a], [b]) and the micro-structure of glacier ice is not further considered here. It is, however, interesting to note that the large rafts of glacier ice visible in the 1960 air photographs had been reduced in 1985 to about one-half of their size. The reduction in size of these glacier remnants over 25 years can be explained by melting as a result of thermoerosion by lake water and eventual incorporation of glacier ice into the lake. Hence, perennially frozen lakes are now expanding at the expense of the adjacent glaciers, a process well illustrated at Bicuspid Lake (Pickard and Adamson, 1983).

The moat varies depending on the season. At the height of summer, the moat is a shallow trough of melt water and granular ice underlain by perennial ice. The moat surrounds the central perennially frozen ice block. As the temperature drops towards the end of summer, freezing forms a smooth ice surface which is bluish in colour. It may have a lace-like appearance (Fig. 3c) caused by small air bubbles between crystals that are generally greater than $2 \mathrm{~cm}$ in diameter.

Perennial ice has a coarser texture than the ice types previously described (Fig. 3a and b). In all perennially frozen lakes at glacier/rock margins, ablational etching has, by late summer, given rise to an uneven ice surface with a variation in relief of around $10 \mathrm{~cm}$. Only at Patterned Lake 

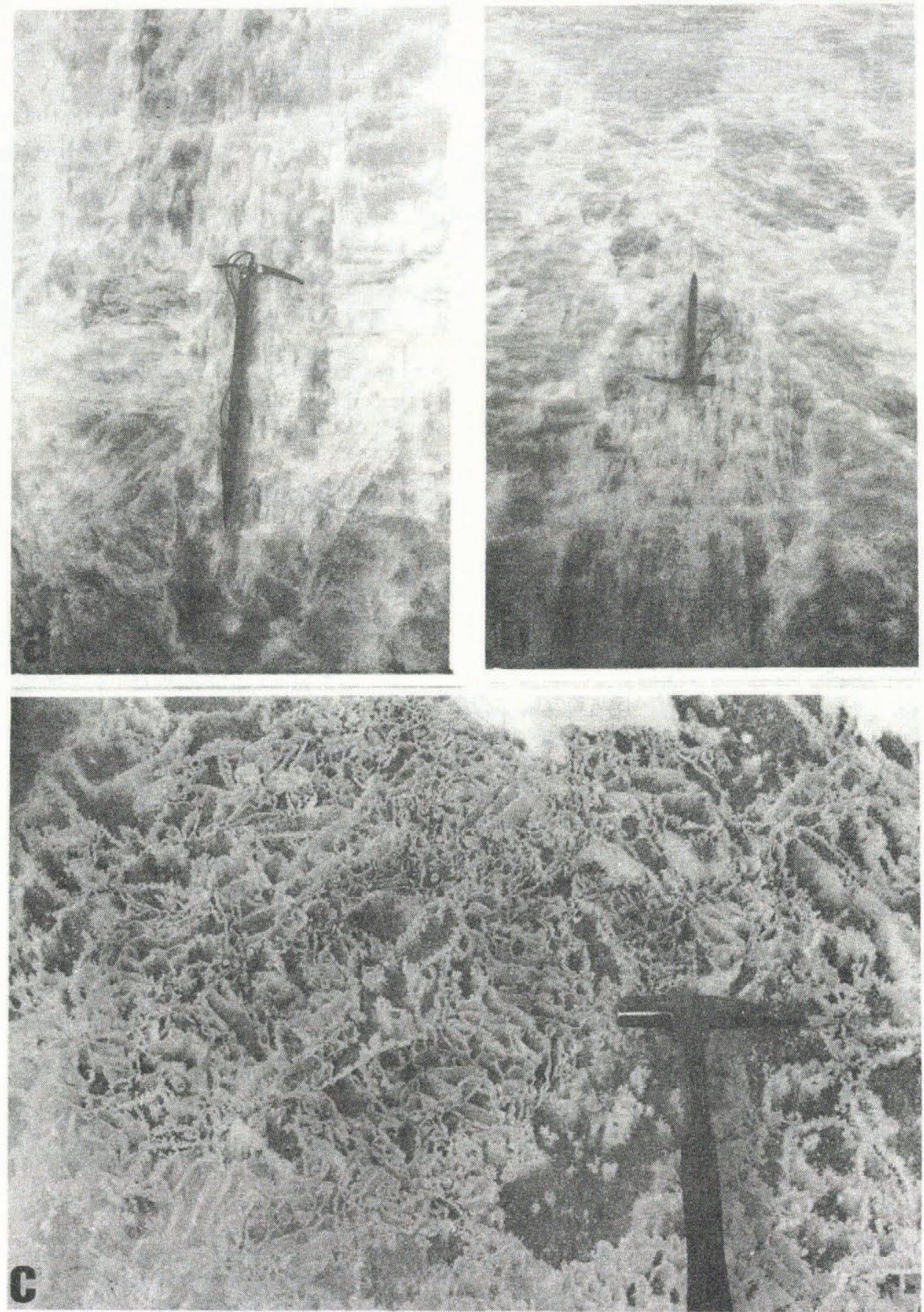

Fig. 3. ( $a$ and b) Typical patterned perennial ice at Patterned Lake. Each pattern is composed of a series of parallel ridges and troughs. The ice axe is $80 \mathrm{~cm}$ long. (c) Typical late summer appearance in moat ice. The lace-like appearance is caused by air bubbles at grain boundaries.

are large-scale individual patterns of several metres clearly developed. On other lakes, small-scale patterned areas may occur, for example, on Rumdoodle Lake. An individual pattern is formed of sets of parallel elongated ridges and troughs approximately $10 \mathrm{~cm}$ relief and $3 \mathrm{~cm}$ spacing. Patterns reach sizes of up to $3 \mathrm{~m} \times 7 \mathrm{~m}$, and penetrate to depths of greater than $1 \mathrm{~m}$. The maximum depth of individual patterns could not be determined because of incomplete core recovery. To the west of the major fracture that cross-cuts the perennial block ( $\mathrm{xx}$ in Figure 2), patterns are not greater than $50 \mathrm{~cm} \times 50 \mathrm{~cm}$. East of this major fracture, individual patterns are usually greater than $100 \mathrm{~cm} \times 50 \mathrm{~cm}$. Patterns are variably orientated with intersecting and cross-cutting relationships (Fig. 5) and, since they are not uniform, it is unlikely that ablational factors such as sun or wind, or any unidirectional force, are responsible for their formation.

\section{TECHNIQUE}

An area of $10 \mathrm{~m} \times 15 \mathrm{~m}$ with large patterns was selected for study (Fig. 4). Additional ice samples from the moat and from the zone of small patterns west of the major fracture ( $x x$ in Figure 2) were obtained. Thin sections of ice were prepared and examined on a Rigsby stage in the field as a guide for sampling. The results presented here are from blocks returned frozen for crystallographic analysis in the School of Earth Sciences, University of Melbourne.

\section{ICE MICROFABRIC}

Table I summarizes the relationships between $c$-axes and the samples analysed. The microscopic observations (Fig. 


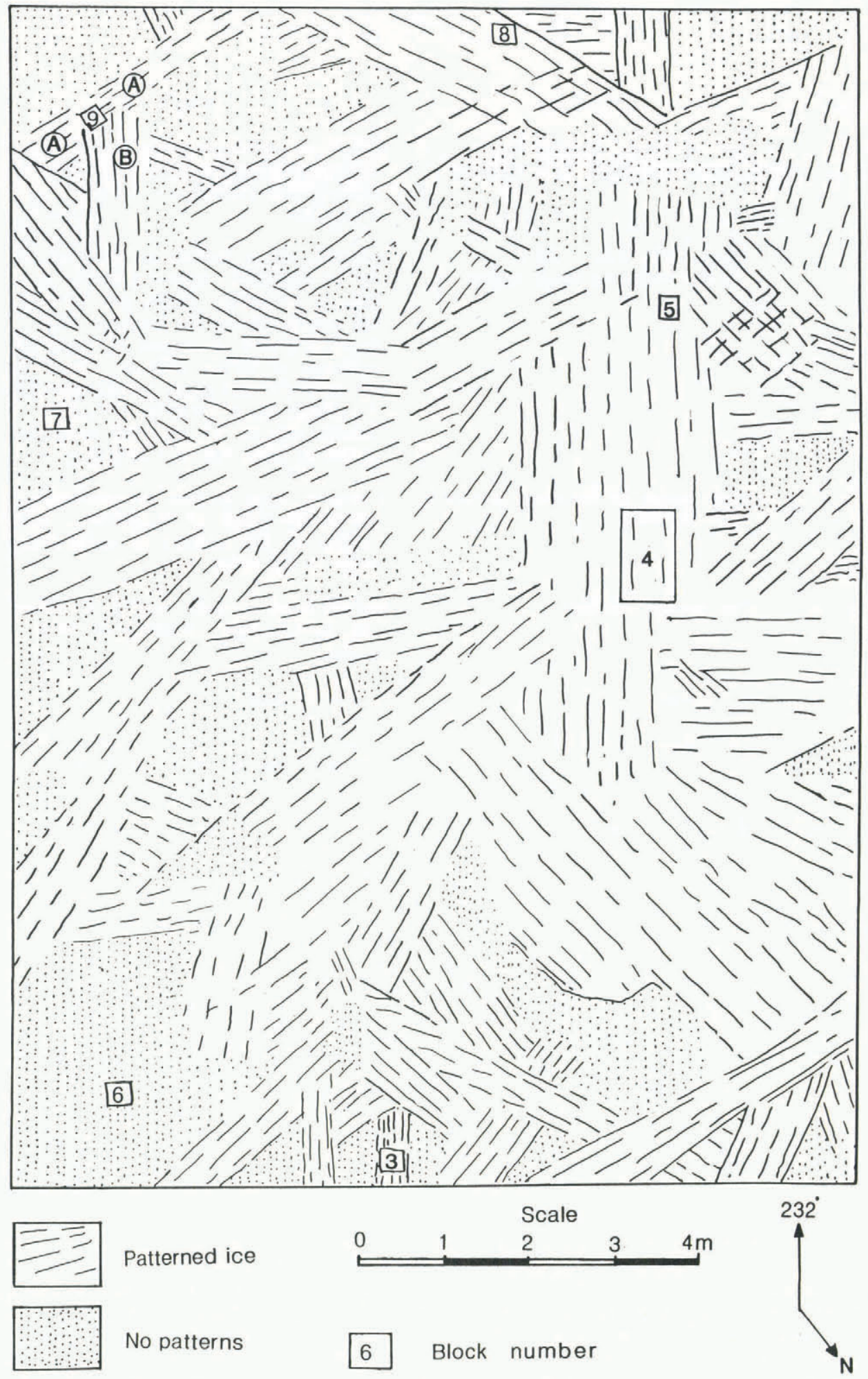

Fig. 4. Field map of the sample area at Patterned Lake showing areas of patterned ice and non-patterned ice. Numbers refer to sampled ice blocks as discussed in the text. A and B refer to the two intersecting patterns sampled in block 9 (see also Figure $5 b$ ).

$5 \mathrm{a}$ and $\mathrm{b}$ ) indicate that individual patterns are composed of large grains that have horizontal dimensional orientations which coincide with that of the surface pattern. Individual grains are tabular in shape and are elongated perpendicular to the ice surface. The same picture can be discerned for other patterned areas. These large grains (long dimension $\geqslant 2 \mathrm{~cm}$ ) have $c$-axes that lie perpendicular to the direction of grain elongation. Intergranular and smaller grains $(\leqslant 1 \mathrm{~cm}$ diameter) located between the larger grains (Fig. 5) are variably orientated with $c$-axes lying within a sub-horizontal plane. The $c$-axes of these small grains cannot be related to the surface patterns.
Ice surfaces devoid of patterns and lying between patterned areas have either (i) $c$-axes variably orientated in a horizontal plane that parallels the ice surface (Fig. 6, block 6) or (ii) vertically orientated $c$-axes (Fig. 6, block 7).

Grain-sizes in regions of intersecting patterns are in general smaller than in areas of large single patterns. The plot of $c$-axes in Figure 6 is inconclusive due to the abundance of randomly orientated but horizontal small grains generally less than $1 \mathrm{~cm}$ in diameter. However, the distribution diagram also presented in Figure $5 \mathrm{~b}$ suggests that two specific orientation groups exist. Each dominant 
TABLE I. DESCRIPTION AND CRYSTALLOGRAPHIC FINDINGS FROM SAMPLED ICE BLOCKS FROM PATTERNED LAKE AS LOCATED IN FIGURES 2 AND 4

Block Orientation

$3230^{\circ}$

$230^{\circ}$

$230^{\circ}$

$-$

7

8

$-$

$358^{\circ}$

$9292^{\circ}$ and $240^{\circ}$

Intersecting patterns

This is part of the same pattern as block 4

No pattern visible

No pattern visible

A typical pattern

Small patterns from the western side of the major fracture as shown in Figure 2

Moat ice

\section{Results}

Ridges of patterns are not related to individual crystals. One crystal may have several ridges as a surface expression

$c$-axes of large crystals are perpendicular to the ridges of the patterns. A map of grains in vertical and horizontal sections along the length of the block is shown in Figure 5. Grain-size estimates of $20 \mathrm{~cm} \times 10 \mathrm{~cm} \times 5 \mathrm{~cm}$ can be made for patterned ice. Large grains frequently show undulose extinction. Smaller crystals lie on a sub-horizontal girdle as indicated in Figure 6

$c$-axes of large crystals are perpendicular to the ridges of the patterns. Hence, within the one pattern the grain orientation is the same

$c$-axes lie in a plane parallel to the ice surface but have no preferred orientation

$c$-axes vertical

$c$-axes are horizontal and perpendicular to the ridges of the patterns, confirming the findings of block 5

$c$-axes lie in a plane parallel to the ice surface but no distinct pattern of orientation can be determined. Two maxima, one towards $200^{\circ}$ and the other towards $150^{\circ}$ correspond to $c$-axes at $90^{\circ}$ to each of the patterns

In each pattern, $c$-axes are perpendicular to the ridges. Grain-size is similar to that in the large patterns. Patterns are composed of less than four grains

$c$-axes lie in a plane parallel to the ice surface. Maximum grain diameter is less than $1.5 \mathrm{~cm}$ orientation is perpendicular to the elongation of one of the intersecting patterns. The relationship suggests competitive growth of patterns has occurred.

The areas of ice with small patterning are generally composed of between one and four grains (Fig. 5c). As a consequence, the overall stereoplot in Figure 6 shows no pattern of preferred orientation. In fact, grains are aligned in small groups as shown in Figure $5 c$ with $c$-axes perpendicular to the elongation of the patterns.

Moat ice forms more rapidly than the perennial ice and consequently grain-sizes are smaller (Fig. 5d). The $c$-axes of most grains are horizontal but no marked pattern of preferred orientation has developed. This is clearly shown in the distribution diagram in Figure $5 \mathrm{~d}$ and in the stereoplot in Figure 6.

\section{DISCUSSION AND CONCLUSIONS}

In many perennially frozen lakes (Michel and Ramseier, 1971) and in most sea ice formed by unidirectional freezing, $c$-axis horizontal orientations develop rapidly after an initial ice skin forms, and they dominate the rest of the ice growth (Weeks and Ackley, 1982). The fast-growth direction of ice crystals, parallel to the basal plane, may be controlled by the temperature gradient (Weeks and Ackley, 1982). In a unidirectional temperature gradient, grains with the basal plane parallel to the temperature gradient can then grow more rapidly than their neighbours. In Patterned Lake, the temperature gradient will be vertical between the underlying stored liquid water and the external Antarctic air. Hence, a $c$-axis horizontal position is favoured. In the perennial ice, individual patterns are composed of elongate tabular grains orientated perpendicular to the surface with $c$-axes showing a preferred orientation in the horizontal plane. This is consistent with the anisotropic growth of individual ice grains parallel to their basal planes (Hobbs, 1974), and with grain boundaries meeting the ice-air or ice-water surfaces at a high angle in order to minimize the grain-boundary interfacial energy (Smith, 1964). In fact, the growth would be very similar to the geometric selection process described in sea ice by Weeks and Ackley (1982). Grains that are not favourably orientated with respect to adjacent grains do not grow as rapidly, or may be eliminated through a process of thermal annealing and migration of boundaries associated with an annealing effect during the following summer. Each summer, partial internal melting and ablation of the perennial ice block occurs preferentially along the aligned grain boundaries, 

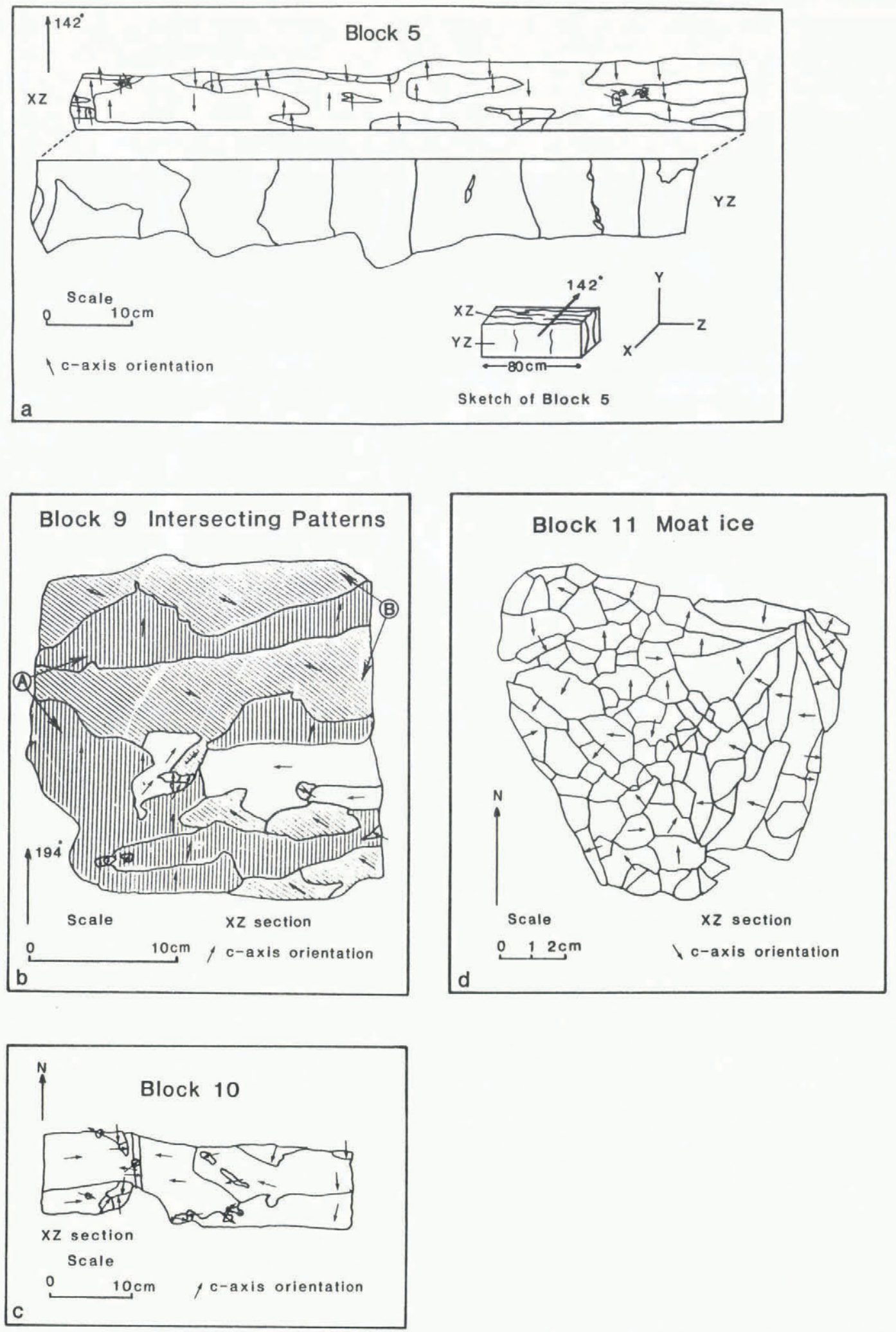

Fig. 5. Maps constructed from numerous thin sections to show approximate grain-size, shape, and the trace of c-axes. (a) Block 5, typical of the large patterns; in large grains c-axes are consistently horizontal and perpendicular to the elongation of patterns. The insert shows the block with reference to axes $\mathrm{XYZ}$ that relate to the lake-ice surface $\mathrm{XZ}$ and the plane perpendicular to this surface $\mathrm{Yz} .(b)$ Block 9, intersecting patterns $A$ and $B$. This distribution diagram shows two dominant orientations as indicated by the shading that roughly parallels the c-axis orientation. Note that the c-axes are perpendicular to the intersecting patterns illustrated in Figure 4. (c) Block 10 is typical of small patterns; several large crystals with parallel c-axes compose each pattern but the orientation does not appear to be consistent throughout. Note the abundance of small grains with variable orientations in the horizontal plane. (d) Typical moat-ice section. c-axes are horizontal but no preferred orientation has developed. 


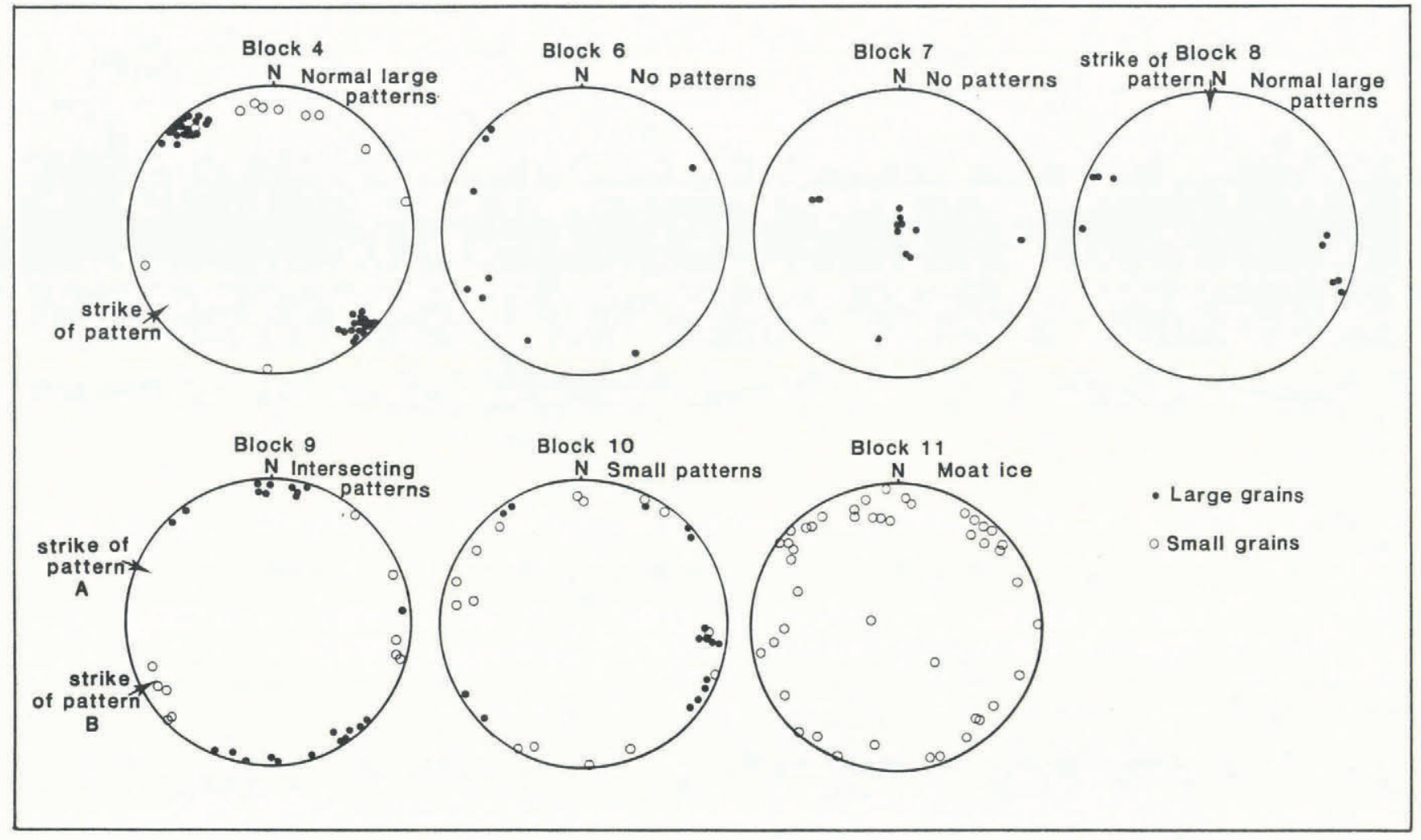

Fig. 6. Equal-area stereographic projections, on lower hemisphere, showing distribution of c-axes in the ice blocks described in Table I. Note that a distinction has been made between the c-axes associated with small and large grains.

leaving a framework of ice below the rigid surface. The framework of partially melted ice probably contains most of the larger crystals from the previous years. Towards the end of summer, crystal growth begins and is controlled by this pre-existing fabric through a process of epitaxial growth. Given that such seasonal processes are operating, it is not hard to see how a large-scale crystallographic orientation develops and how larger grains are able to grow over a long period of time.

Small patterning, as found to the east of the major fracture, probably represents an intermediate stage between that of the moat ice and the perennial ice. This part of Patterned Lake is adjacent to the north-west corner where most water runs into the lake during summer, and it is likely that more extensive internal and surface melting of the ice block occurs. As a result, large patterns have not developed. There is a greater abundance of small grains of uniform distribution of $c$-axes in a horizontal plane in ice with small patterns.

\section{ACKNOWLEDGEMENTS}

The Australian Antarctic Division is thanked for logistic support and the supply of cold-room facilities used for analysis of the ice samples. J.L.C.C. acknowledges a University of Melbourne summer studentship awarded by the Science Faculty, which enabled him to undertake this work. I. Allison is thanked for his discussion of our field observations. D.A.A. acknowledges financial support from Australian Research Grants Scheme and Macquarie University. J. Pickard's contributions to the study of perennially frozen lakes near Mawson and his help with drilling on Patterned Lake in 1979 were invaluable.

\section{REFERENCES}

Budd, W.F. 1967. Ablation from an Antarctic ice surface (In Oura, H., ed. Physics of Snow and Ice: International Conference on Low Temperature Science. ... 1966. ... Proceedings, Vol. 1, Pt. 1. [Sapporo], Hokkaido University. Institute of Low Temperature Science, p. 431-46.)

Crohn, P.W. 1959. A contribution to the geology and glaciology of the western part of Australian Antarctic Territory. Bureau of Mineral Resources, Geology and Geophysics. Bulletin, No. 52.

Hobbs, P.V. 1974. Ice physics. Oxford, Clarendon Press.

Illingsworth, J.J. Unpublished. Energy balance studies at Mawson, Antarctica. [M.Sc. thesis, University of Melbourne, 1967.]

Kizaki, K. 1969[a]. Fabric analysis of surface ice near Casey Range, East Antarctica. Journal of Glaciology, Vol. 8 , No. 54 , p. $375-83$.

Kizaki, K. 1969[b]. Ice-fabric study of the Mawson region, East Antarctica. Journal of Glaciology, Vol. 8, No. 53, p. 253-76.

Michel, B., and Ramseier, R.O. 1971. Classification of river and lake ice. Canadian Geotechnical Journal, Vol. 8, No. 1 , p. $36-45$.

Pickard, J., and Adamson, D.A. 1983. Perennially frozen lakes at glacier/rock margins, East Antarctica. (In Oliver, R.L., and others, eds. Antarctic earth science. Edited by R.L. Oliver, P.R. James, and J.B. Jago. Cambridge, etc., Cambridge University Press, p. 470-72.)

Smith, C.S. 1964. Some elementary principles of polycrystalline microstructure. Metallurgical Review, Vol. 9, No. 1, p. 1-48.

Weeks, W.F., and Ackley, S.F. 1982. The growth, structure, and properties of sea ice. CRREL Monograph (Hanover, NH) $82-1$. 